\title{
INFORMATION AND COMMUNICATION TECHNOLOGIES DEVELOPMENT INDEX: GLOBAL ANALYSIS AND DIGITAL DIVIDES
}

\author{
DOI: 10.17261/Pressacademia.2019.1118 \\ RJBM-V.6-ISS.3-2019(3)-p.167-174 \\ Tugba Guz ${ }^{1}$, Gulden Poyraz ${ }^{2}$ \\ ${ }^{1}$ Istanbul Yeni Yuzyil University, Department of Health-Care Management, 34010, Istanbul, Turkey \\ tugbaguz@gmail.com , ORCID: 0000-0003-1644-7803 \\ 2 Istanbul University, Department of Economics, 34452, Istanbul, Turkey, \\ poyrazgulden06@gmail.com , ORCID: 0000-0002-8324-6270
}

Date Received: June 3, 2019

Date Accepted: September 19, 2019

\section{To cite this document}

Guz, T., Poyraz, G., (2019). Information and communication technologies development index: global analysis and digital divides. Research Journal of Business and Management (RJBM), V.6(3), p.167-174

Permemant link to this document: http://doi.org/10.17261/Pressacademia.2019.1118

Copyright: Published by PressAcademia and limited licenced re-use rights only.

\begin{abstract}
Purpose - The aim of this study is determining the development level of 80 countries in the ICT, measuring the performance of countries over time and revealing the digital divisions among the countries.

Methodology - Following the methodology used by the International Telecommunication Union, ICT Development Index (ICTDEV-I) of 80 countries are calculated separately for each year from 2010 to 2016. To calculate the index and determine the weight of each indicator, the Factor analysis is used and the Principal Component Analysis is chosen. The countries are grouped according to their ICT levels to reveal and compare digital divisions among them.

Findings- The countries are ranked according to the index values and comparative analysis are presented. The size of the digital divide and whether shrink of this division among the countries is analyzed.

Conclusion- There is an increase in the index values of all countries included in the ICTDEV-I. Digital divisions are increased between developing and less developed countries.
\end{abstract}

Keywords: information and communication technologies (ICT), ICT Development Index, digital divides, technology, human capital JEL Codes: 011, 033, 034

\section{INTRODUCTION}

Information and Communication Technologies (ICT) has a strong impact on sustainable economic growth and global competition. The countries that have skills and required infrastructure to use these technologies and can access to adapt to the speed of these technologies benefit from the strong impact of ICT. In this direction, countries that can transform the information they produce into technology and invest in human capital on the basis of ICT can have the potential to be a leader in the global as well as a sustainable competitive advantage.

ICT has become a strategic power. Therefore, as much as the production of ICT, widespread usage, and the establishment of an appropriate infrastructure have gain importance in terms of increasing the efficiency of these technologies. In this process, countries take into account their dynamics in order to benefit from the strong impact of ICT. Therefore, they identify the areas that transformations are needed and making changes in their existing structures. Moreover, they develop a national strategy by enhancing various analyses, comparisons, and methods that measure the impact of ICT.

The aim of this study is determining the development level of 80 countries in the ICT, measuring the performance of countries over time in these technologies and revealing the digital divisions among the countries. In this context, the digital divide between the countries is considered within the scope of ICT Development Index (ICTDEV-I) and the countries are examined globally. For 
this purpose, ICTDEV-I of 80 countries are calculated separately for each year from 2010 to 2016, and ICT development levels are examined on a global scale.

The organization of this paper is as follows; A brief review of the empirical literature is presented in section two. In the third section, the data set and the methodology are given. Findings and discussions are mentioned in the fourth section. These sections are followed by the conclusion part.

\section{LITERATURE REVIEW}

International Telecommunication Union is publishing "Measuring the Information Society" report as annually since 2009. The report examines the level of ICT development of countries over time and makes comparative analyses as global, regional, and according to the level of development of countries. In addition to this, digital divides between countries are being evaluated. In the report, countries are evaluated on the basis of 11 indicators in terms of ICT access, skills, and use. In this direction, the ICT Development Index (IDI) is composed. In the 2017 report, IDI is generated using data from 176 countries. While developed countries such as Iceland, Korea (Rep.), Switzerland are at the top of the index, the countries such as Eritrea, Central African Rep., Chad are bottom of the index. In the 2017 report, the regional analysis indicated that the highest region in terms of average IDI performance is the European Region. As to the average of Africa is below the average of other regions (ITU, 2017).

Camara and Tuesta (2017) composed an index called DiGiX in their study. The index consists of six dimensions as infrastructure, households' adoption, enterprises adoption, costs, regulation, and contents. It also includes 21 indicators. They evaluated the 100 countries in terms of their digital performances. While countries such as Luxembourg, the United Kingdom, and the United States are at the top of the index, lower African countries such as Algeria and Cameroon are in the lower ranks.

Erumban and Das (2016) examined the sources of economic growth in the Indian economy on the basis of ICT since the 1980s. In their study, they analysed the effects of ICT on economic growth in two ways as indirect and direct. They examined the direct contribution of ICT investments on total economy and manufacturing sector and they analysed the indirect effect of these technologies on total factor productivity increase in the sectors that use and produce ICT. Along with largely limited to the service sector, they concluded that ICT investment has an increasing role in driving economic growth in India.

Malisuwan et al. (2015) re-weighted the eleven indicators of ITU's ICT Development Index by taking into account the dynamics of Thailand. In this context, they investigated how Thailand could become a leading country in ICT among ASEAN countries. They analysed the weakness points of ICT development of Thailand and they found that there are 5 weak indicators out of 11 . They also predicted that they could take first place among ASEAN countries in 2020.

Katz et al. (2013) constituted an index called "Digitalization Index" to demonstrate the digital progress of 184 Latin American countries, between the years of 2004-2011. The index is consisting of six factors as ubiquity, affordability, reliability, speed, usability, and skill. It is containing 24 sub-indicators. They divided the 184 counties into four categories as constrained, emerging, transitional and advanced in the index. In their study, they found that the Latin American region is relatively fast in increasing the level of digitalization and that there are significant differences between countries. They also stated that the difficulties faced by each of the countries that are divided into four categories in the index are different. They also indicate that digitalization contributed to economic growth in a certain proportion.

Farhadi et al. (2012) using the variables included in the ICT usage index, examined the effect of the use of ICT on economic growth between the years 2000 and 2009 in the framework of the dynamic panel data approach with Generalized Method of Moments (GMM). As a result of their studies, they suggested that there is a positive relationship between per capita GDP growth rate and ICT usage index. In addition, they divided 159 countries into four different income groups as high, medium-high, medium-low and low-income by using the ITU classification. They suggested that the impact of ICT usage on economic growth is greater in the highincome country group.

\section{DATA AND METHODOLOGY}

In this study, ICT Development Index is calculated for each year from 2010 to 2016 in order to reveal the level of development of ICT of 80 countries where the data is reached. Between the years mentioned in this study, primarily, 180 countries are taken into account. But, with the removal of missing data from the data set, the number of countries is reduced to 80 . In this context, the ICT development levels of the countries are analyzed comparatively in terms of global dimension and digital divisions.

The data used to determine the level of ICT Development of the 80 countries included in the index and the resources used to reach these data are given in Table 1. 
Table 1: Dataset and Resources

\begin{tabular}{ll}
\hline ICT Development Index & Resources \\
\hline ICT Access Indicators & \\
\hline 1- Fixed telephone subscriptions per 100 inhabitants & \\
2- Mobile-cellular telephone subscriptions per 100 inhabitants & \\
3- International internet bandwidth (bit/s) per internet user & ITU \\
4- Percentage of households with a computer & \\
5- Percentage of households with internet access & \\
\hline ICT Use Indicators & ITU \\
\hline 6- Percentage of individuals using the internet & \\
7- Fixed-broadband subscriptions per 100 inhabitants & \\
8- Active-mobile broadband subscriptions per 100 inhabitants & \\
\hline ICT Skills Indicators & UNESCO \\
\hline 9- Mean Years of Schooling & World Bank \\
10- Secondary gross enrolment ratio & \\
11- Tertiary gross enrolment ratio & \\
\hline
\end{tabular}

The distance to the reference measure is used to normalize the data. The reference measure is the ideal value accessible for each indicator (similar to a goalpost). This value is taken as $\mathbf{1 0 0}$ for other indicators except for the five indicators in the Index. The weight of each of the 11 indicators that ITU weighted equally is recalculated using the weighting methods of the ITU. Factor Analysis, one of the dimension reduction methods, is used in order to calculate the index and to determine the weight of each indicator. In this analysis, the Principal Component Analysis method is chosen. In these methods, the variance explanation percentages and the values of the factor loads are used to calculate the weight of each of the 11 indicators in the index. The weight of each indicator is calculated according to the results obtained from the factor analysis which explained the relative importance of the indicators in each subgroup (Access, Use, Skills sub-indices) in the index ${ }^{1}$ (ITU, 2009). The results derived from Principal Component Analysis are given in Table 2 and the results obtained from Factor Analysis for 12 regions, the calculated weights for each indicator, and ideal values are given in Table 3.

Table 2: The Results of Principal Component Analysis

\begin{tabular}{llll}
\hline & Eigenvalues & $\begin{array}{l}\text { Share of Variance } \\
\text { Explained (\%) }\end{array}$ & $\begin{array}{l}\text { Cumulative Share of } \\
\text { variance Explained (\%) }\end{array}$ \\
\hline ICT Access Indicators & & & \\
\hline Component 1 & 3.490 & 69.799 & 69.799 \\
Component 2 & 0.884 & 17.684 & 87.483 \\
Component 3 & 0.360 & 7.198 & 94.681 \\
Component 4 & 0.235 & 4.704 & 99.385 \\
Component 5 & 0.031 & 0.615 & 100.000 \\
KMO / Bartlett's Test & $0.76 /$ Ch-Sq (369.005) & $(p-v a l u e=0.000)$ & \\
\hline ICT Use Indicators & & & \\
\hline Component 1 & 2.549 & 84.982 & 94.982 \\
Component 2 & 0.333 & 11.108 & 100.000 \\
Component 3 & 0.117 & 3.910 & \\
KMO / Bartlett's Test & $0.71 /$ Ch-Sq (177.942) & $(p-v a l u e=0.000)$ \\
\hline ICT Skills Indicators & \multicolumn{3}{l}{} \\
\hline
\end{tabular}

\footnotetext{
${ }^{1}$ As a result of the factor analysis, the weights of each indicator are calculated following the ITU methodology. First, the component loadings are squared and divided by the share of variance explained by the component. Obtained results are multiplied by the ratio of the variance explained by the component and total variance. Then, the derived weights are rescaled to sum up to 100 to increase comparability.
} 


\begin{tabular}{llll}
\hline Component 1 & 2.319 & 77.285 & 77.285 \\
Component 2 & 0.384 & 12.809 & 90.094 \\
Component 3 & 0.297 & 9.906 & 100.000 \\
KMO / Bartlett's Test & $0.73 /$ Ch-Sq (102.544) & (p-value = 0.000) & \\
\hline
\end{tabular}

Table 3: Component Loadings, Ideal Values, and Indicator Weight

\begin{tabular}{|c|c|c|c|c|}
\hline & $\begin{array}{c}\text { Component } \\
\text { Loadings }\end{array}$ & $\begin{array}{c}\text { Ideal } \\
\text { Values }\end{array}$ & $\begin{array}{l}\text { Indicator } \\
\text { Weights }\end{array}$ & $\%$ \\
\hline \multicolumn{5}{|l|}{ ICT Access Indicators } \\
\hline 1- Fixed telephone subscriptions per 100 inhabitants & 0.683 & 60 & 0.13 & \multirow{5}{*}{40} \\
\hline $\begin{array}{l}\text { 2-Mobile-cellular telephone subscriptions per } 100 \\
\text { inhabitants }\end{array}$ & 0.972 & 170 & 0.25 & \\
\hline 3- International internet bandwidth (bit/s) per internet user & 0.830 & 6.39 & 0.19 & \\
\hline 4- Percentage of households with a computer & 0.904 & 100 & 0.22 & \\
\hline 5- Percentage of households with internet access & 0.920 & 100 & 0.22 & \\
\hline \multicolumn{5}{|l|}{ ICT Use Indicators } \\
\hline 6- Percentage of individuals using the internet & 0.953 & 100 & 0.36 & \multirow{3}{*}{40} \\
\hline 7- Fixed-broadband subscriptions per 100 inhabitants & 0.933 & 43 & 0.34 & \\
\hline 8-Active-mobile broadband subscriptions per 100 inhabitants & 0.878 & 100 & 0.30 & \\
\hline \multicolumn{5}{|l|}{ ICT Skills Indicators } \\
\hline 9- Mean Years of Schooling & 0.859 & 15 & 0.33 & \multirow{3}{*}{20} \\
\hline 10- Secondary gross enrolment ratio & 0.890 & 100 & 0.34 & \\
\hline 11- Tertiary gross enrolment ratio & 0.888 & 100 & 0.34 & \\
\hline
\end{tabular}

In this respect, the ICT Development Index values of the 80 countries are calculated by using the weights are given in Table 3 and the ideal values applied in the normalization process of the data. Following the ITU methodology, equal weight is given 40 percent to each of the sub-indices of ICT access and ICT usage in the calculation of the final index. The ICT skills sub-index is given 20 percent weight because it is based on a proxy indicator. ${ }^{2}$ In the final stage, the weights of the sub-indices are collected and the index value of each country is calculated. When calculating the index value of countries, the indicator values of countries are divided into ideal values and multiplied by the weights of each indicator. The derived values are collected and multiplied with the weight of each sub-index. As a result of this process, the values derived for each sub-index is collected and multiplied by 10 and the index values of the countries are found. All these transactions are calculated separately for each of the 80 countries in the index.

The ICT Development Index is used to determine the magnitude of the digital divide between countries and examine its development over time. In this respect, countries are grouped according to their ICT levels and the digital divide between them is presented comparatively for the years of 2010 and 2016. The following steps are applied in the determination of digital divide between the 80 countries.

- The average of the ICT Development Index values of 80 countries is taken. While the average value for 2016 is 6.77 , this value is calculated as 5.26 for 2010 .

- $\quad$ Countries are divided into four groups as two groups above average and two groups below average. The countries above the average are called as the high group and upper-middle group. The countries below the average are called as lowermiddle groups and low groups.

- $\quad$ The countries above and below the average are divided into two equal groups.

2 Since the indicators that are directly related to their ICTs are not available in many countries, the three indicators used in the skills sub-index to measure educational performance in countries are taken as proxy variables. Therefore, less weight (20\%) is given to the skill sub-index according to the other two sub-indices. In addition, education indicators tend to move more slowly than indicators in the access and use sub-indices. 
According to these calculations, the index values of the groups are given in Table 4.

Table 4: Country Groups with Different level of ICT

\begin{tabular}{lcccc}
\hline Group & $\begin{array}{c}\text { Number of } \\
\text { Countries 2016 }\end{array}$ & $\begin{array}{c}\text { ICTDEV-I Value } \\
\mathbf{2 0 1 6}\end{array}$ & $\begin{array}{c}\text { Number of } \\
\text { Countries 2010 }\end{array}$ & $\begin{array}{c}\text { ICTDEV-I } \\
\text { Value 2010 }\end{array}$ \\
\hline High & 23 & 8.08 and above & 20 & 7.08 and above \\
\hline Upper-middle & 22 & $6.92-8.06$ & 20 & $5.34-7.05$ \\
\hline Lower-middle & 18 & $5.26-6.65$ & 20 & $3.55-5.18$ \\
\hline Low & 17 & $1.87-5.15$ & 20 & $1.43-3.45$ \\
\hline
\end{tabular}

\section{FINDINGS AND DISCUSSIONS}

The index values of the 80 countries, that are calculated separately for the years of 2010 and 2016 are comparatively given in Table 5. It is seen that there is an increase in the index values of all countries included in the ICT Development Index between 2010 and 2016. Overall, all the countries improved their scores over the seven-year period. The countries with high-income level such as Denmark, Republic of Kore, Sweden, Hong Kong, Iceland, Australia are rank top of the index between the mentioned years. In general, the least developed countries with low-income levels such as Benin, Pakistan, Bangladesh, Senegal, and Zimbabwe are rank at the bottom of the index. A little change is occurred in the index ranking of these countries within seven years. The index values of these countries are low consistently with their economic development.

Table 5: ICT Development Index (ICTDEV-I), Comparison of 2010-2016

\begin{tabular}{|c|c|c|c|c|c|c|c|c|c|}
\hline Countries & $\begin{array}{l}2016 \\
\text { Rank }\end{array}$ & $\begin{array}{l}\text { Index } \\
\text { Value } \\
2016\end{array}$ & $\begin{array}{l}2010 \\
\text { Rank }\end{array}$ & $\begin{array}{c}\text { Index } \\
\text { Value } \\
2010\end{array}$ & Countries & $\begin{array}{l}2016 \\
\text { Rank }\end{array}$ & $\begin{array}{c}\text { Index } \\
\text { Value } \\
2016\end{array}$ & $\begin{array}{l}2010 \\
\text { Rank }\end{array}$ & $\begin{array}{c}\text { Index } \\
\text { Value } \\
2010\end{array}$ \\
\hline Denmark & 1 & 9.49 & 3 & 8.40 & Hungary & 41 & 7.08 & 33 & 6.02 \\
\hline Hong Kong & 2 & 9.46 & 9 & 7.78 & Kazakhstan & 42 & 7.07 & 48 & 4.63 \\
\hline Australia & 3 & 9.31 & 13 & 7.51 & Argentina & 43 & 7.04 & 42 & 4.96 \\
\hline Iceland & 4 & 9.28 & 5 & 8.21 & Bulgaria & 44 & 6.94 & 40 & 5.34 \\
\hline Finland & 5 & 9.19 & 6 & 8.18 & Costa Rica & 45 & 6.92 & 56 & 3.97 \\
\hline Sweden & 6 & 9.17 & 2 & 8.40 & Malaysia & 46 & 6.65 & 47 & 4.71 \\
\hline Korea (Rep.) & 7 & 9.13 & 1 & 8.59 & Chile & 47 & 6.65 & 46 & 4.75 \\
\hline Switzerland & 8 & 9.09 & 10 & 7.71 & Jordon & 48 & 6.50 & 60 & 3.55 \\
\hline Netherlands & 9 & 9.00 & 7 & 8.11 & Romania & 49 & 6.50 & 43 & 4.95 \\
\hline United Kingdom & 10 & 8.97 & 11 & 7.68 & Moldova & 50 & 6.46 & 52 & 4.06 \\
\hline Norway & 11 & 8.93 & 4 & 8.36 & Lebanon & 51 & 6.44 & 54 & 4.01 \\
\hline Japan & 12 & 8.93 & 12 & 7.63 & Turkey & 52 & 6.19 & 49 & 4.27 \\
\hline Esthonia & 13 & 8.83 & 22 & 6.77 & Macedonia & 53 & 6.13 & 45 & 4.83 \\
\hline Luxemburg & 14 & 8.83 & 8 & 8.02 & Brazil & 54 & 6.07 & 53 & 4.05 \\
\hline New Zealand & 15 & 8.59 & 17 & 7.29 & Thailand & 55 & 6.06 & 68 & 3.27 \\
\hline United States & 16 & 8.57 & 15 & 7.30 & Mauritius & 56 & 6.00 & 55 & 3.97 \\
\hline Germany & 17 & 8.51 & 14 & 7.44 & Georgia & 57 & 5.93 & 59 & 3.60 \\
\hline France & 18 & 8.45 & 16 & 7.30 & China & 58 & 5.74 & 63 & 3.42 \\
\hline Belgium & 19 & 8.45 & 19 & 7.16 & Ukraine & 59 & 5.71 & 50 & 4.22 \\
\hline Austria & 20 & 8.39 & 21 & 7.05 & Bosnia-Herzegovina & 60 & 5.54 & 57 & 3.92 \\
\hline Ireland & 21 & 8.29 & 20 & 7.08 & Colombia & 61 & 5.39 & 58 & 3.63 \\
\hline Canada & 22 & 8.12 & 18 & 7.22 & Mexico & 62 & 5.26 & 61 & 3.45 \\
\hline Malta & 23 & 8.08 & 25 & 6.59 & Panama & 63 & 5.26 & 51 & 4.20 \\
\hline Spain & 24 & 8.06 & 26 & 6.51 & Albania & 64 & 5.15 & 62 & 3.45 \\
\hline Israel & 25 & 8.00 & 23 & 6.71 & South Africa & 65 & 5.07 & 65 & 3.38 \\
\hline Cyprus & 26 & 7.92 & 31 & 6.23 & Ecuador & 66 & 4.91 & 67 & 3.32 \\
\hline Qatar & 27 & 7.66 & 36 & 5.94 & Jamaica & 67 & 4.82 & 64 & 3.40 \\
\hline Belarus & 28 & 7.66 & 41 & 5.18 & Tunusia & 68 & 4.80 & 66 & 3.35 \\
\hline Latvia & 29 & 7.55 & 32 & 6.21 & Morocco & 69 & 4.78 & 69 & 3.27 \\
\hline Slovenia & 30 & 7.55 & 24 & 6.65 & Algeria & 70 & 4.65 & 72 & 2.78 \\
\hline
\end{tabular}




\begin{tabular}{|c|c|c|c|c|c|c|c|c|c|}
\hline Lithuania & 31 & 7.47 & 29 & 6.33 & Egypt & 71 & 4.57 & 70 & 3.18 \\
\hline Uruguay & 32 & 7.46 & 44 & 4.87 & Dominican Rep. & 72 & 4.51 & 71 & 3.08 \\
\hline Russia & 33 & 7.44 & 38 & 5.71 & Kyrgyzstan & 73 & 4.39 & 73 & 2.74 \\
\hline Greece & 34 & 7.44 & 34 & 6.00 & Indonesia & 74 & 4.37 & 74 & 2.66 \\
\hline Czech Republic & 35 & 7.36 & 28 & 6.34 & India & 75 & 3.00 & 75 & 1.91 \\
\hline Portugal & 36 & 7.32 & 37 & 5.88 & Zimbabwe & 76 & 2.82 & 76 & 1.64 \\
\hline Croatia & 37 & 7.28 & 39 & 5.67 & Senegal & 77 & 2.57 & 79 & 1.51 \\
\hline Slovakia & 38 & 7.26 & 35 & 5.96 & Bangladesh & 78 & 2.56 & 80 & 1.43 \\
\hline Italy & 39 & 7.21 & 27 & 6.43 & Pakistan & 79 & 2.37 & 77 & 1.62 \\
\hline Poland & 40 & 7.14 & 30 & 6.29 & Benin & 80 & 1.87 & 78 & 1.53 \\
\hline
\end{tabular}

As it can be seen from the Table 6, the average of the ICTDEV-I increased by $28.7 \%$ from 5.26 to 6.77 between 2010 and 2016. When the average changes in the sub-indices are taken into consideration, the access sub-index is $15.7 \%$, use sub-index is $68.8 \%$, skill sub-index is $6.3 \%$ increased within seven years. The average value of the ICT use sub-index increased by $68.8 \%$ over 7 years and increased faster than the other two sub-indices. The skill sub-index increased less than the other two sub-indices, as previously mentioned, the indicators that make up this sub-index consist of proxy indicators and less weight than the other two sub-indices (20\%).

Table 6: ICTDEV-I and Change Values of the Sub-Indices between the Years 2010-2016

\begin{tabular}{lcccc}
\hline & Average Value & Average Value & \multicolumn{2}{c}{$\begin{array}{c}\text { Change in Average } \\
\text { Value in 2010-2016 }\end{array}$} \\
\cline { 2 - 5 } & $\mathbf{2 0 1 0}$ & $\mathbf{2 0 1 6}$ & Difference & \% \\
\hline ICTDEV-I & 5.26 & 6.77 & 1.51 & 28.7 \\
\hline Access sub-index & 5.81 & 6.72 & 0.91 & 15.7 \\
\hline Use sub-index & 3.78 & 6.38 & 2.60 & 68.8 \\
\hline Skills sub-index & 7.12 & 7.57 & 0.45 & 6.3 \\
\hline
\end{tabular}

The average of the ICTDEV-I values for the countries divided into four groups in order to reveal the digital divisions between countries is shown in Table 7. There is an increase in group averages within the seven-year period. The increase in high and uppermiddle groups is less than the lower-middle and low groups. The reason is that, most of the countries in these groups are developed countries with high-income levels. In this respect, it can be concluded that the ICT infrastructure, services, and acquisition in these countries are already maturing and that these countries have more advanced digital services and high-speed broadband connections.

Table 7: ICTDEV-I Group Averages

\begin{tabular}{lcccc}
\hline Group & $\begin{array}{c}\text { ICTDEV-I } \\
\text { Average Value 2010 }\end{array}$ & $\begin{array}{c}\text { ICTDEV-I } \\
\text { Average Value 2016 }\end{array}$ & Difference & \% \\
\hline High & 7.77 & 8.83 & 1.06 & 13.6 \\
\hline Upper-middle & 6.23 & 7.40 & 1.17 & 18.8 \\
\hline Lower-middle & 4.32 & 6.03 & 1.71 & 39.6 \\
\hline Low & 2.72 & 3.95 & 1.23 & 45.2 \\
\hline All the countries & 5.26 & 6.77 & 1.51 & 28.7 \\
\hline
\end{tabular}

While most of the countries in the lower-middle group comprise of developing countries, the countries in the low group consist of less developed and developing countries. The average index values of developing countries reveal that these countries perform better than less developed countries. On the other hand, the initial index values of the less developed countries in 2010 are lagging behind the developing countries. Although, these countries have slightly improved their index values within seven years, their ranking in the general index is not remarkably changed. For instance, Benin took third place with 1.53 points at the end of the index rank in 2010. Although increased the index value to 1.87 in 2016, it remained at the end of the index rank.

In order to evaluate whether the digital divide between the countries is growing or shrinking, the changing in the index values of the groups over time are taken into consideration. The variation of the digital divide between the groups is evaluated in Table 8 .

Table 8: Evaluation of the Digital Divide between the Groups 


\begin{tabular}{llccc}
\hline & & \multicolumn{2}{c}{$\begin{array}{c}\text { The Magnitude of } \\
\text { The Digital Divide }\end{array}$} & $\begin{array}{c}\text { Change in the } \\
\text { Digital Divide }\end{array}$ \\
\cline { 3 - 5 } & & $\mathbf{2 0 1 0}$ & $\mathbf{2 0 1 6}$ & $\mathbf{2 0 1 0 - 2 0 1 6}$ \\
\hline High & Low & 5.05 & 4.88 & -0.2 \\
\hline High & Lower-middle & 3.45 & 2.80 & -0.7 \\
\hline High & Upper-middle & 1.54 & 1.43 & -0.1 \\
\hline Upper-middle & Low & 2.28 & 3.45 & 1.2 \\
\hline Upper-middle & Lower-middle & 1.91 & 1.37 & -0.5 \\
\hline Lower-middle & Low & 1.60 & 2.08 & 0.4 \\
\hline
\end{tabular}

The rate of closure of the digital divide varies between countries. For instance, the difference in the magnitude of the digital divide between the high and low group $(-0.2)$ is slightly shrinking. It can be said that the difference between developed countries and especially developing countries with high per capita GDP is decreased. Likewise, among the developing countries with relatively low per capita GDP levels in these countries, the digital divide in essential services is relatively reduced by the widespread use of mobile phones and mobile broadband. Despite all, digital divides and inequalities continue to affect the countries, although continues progress in connectivity and use of ICTs in all over the world.

\section{CONCLUSION}

In this study, ICT development levels of 80 countries are considered within the scope of the ICT development index and evaluated globally. In this direction, the performance of countries in these technologies over time is measured. In addition to this, digital divides between countries are revealed. For this purpose, ICTDEV-I of 80 countries are calculated separately for each year from 2010 to 2016, and ICT development levels are examined on a global scale. The ICT Development Index is used to determine the magnitude of the digital divide among countries and examine its development over time. In this respect, countries are grouped according to their ICT levels and the digital divide between them is presented comparatively for the years 2010 and 2016.

When the calculated ICT Development Index is evaluated, it is seen that the average of the index increased by $28.7 \%$ in seven years. It can be said that the countries placed at the top of the index rank invest in the ICT infrastructure at a high level and have high-speed networks and broadband services. They also develop comprehensive action plans, policies and strategies from education to the business world in order to maintain their position as the leading country in digital transformation and to compete in this change process. The countries in the lower ranks of the index shown little change in the index ranking within seven years. ICT development index values of these countries can be said to be low, consistent with their economic development.

Considering the digital divisions between countries, it can be said that the difference between the ICT level of developing countries and the ICT level of less developed countries are increased. Considering that the ICT has a positive impact on the social and economic development of the countries, it can be concluded that this difference between the groups of countries may open the gap between the other development indicators. However, the difference between developed countries and especially developing countries with high per capita GDP is decreased. Likewise, among the developing countries with relatively low per capita GDP levels in these countries, the digital divide in essential services is relatively reduced by the widespread use of mobile phones and mobile broadband. But, especially, new technology trends such as differences in broadband technologies between countries, big data analysis, artificial intelligence, autonomous robotics technology, cloud computing, cyber-physical systems, the Internet of things are expected to lead to an expansion of the digital divide between countries.

\section{REFERENCES}

Camara, N. Tuesta, D. (2017). DiGiX: The digitization index. Working Paper, BBVA Research. 17(03): 2-17.

Erumban, A. A. Das, D. K. (2016). Information and communication technology and economic growth in India. Telecommunication Policy. 40(5): 412-431. DOI: 10.1016/j.telpol.2015.08.006

Farhadi, M. Ismail, R. Fooladi, M. (2012). Information and Communication Technology Use and Economic Growth. PLoS One. 7(11): 1-7. DOI: 10.1371/journal.pone.0048903

International Telecommunication Union (ITU) (2017). Measuring the information society report 2017. 1: 1-170.

International Telecommunication Union (ITU) (2009). Measuring the information society, the ICT development Index. 1-108. 
Katz, R. L. Koutroumpis, P. Callorda, F. (2013). The Latin American path towards digitization. Info, Emerald Group Publishing Limited. $15(3):$ 6-24. DOI: $10.1108 / 14636691311327098$

Malisuwan, S. Milindavanij, D. Sivaraks, J. Tiamnara, N. (2015). A Modified Model of ICT Development Index (IDI) For Thailand to Achieve The ICT Leader in ASEAN." International Journal of Advanced Research in Engineering and Technology (IJARET). 6 (12): 39-48. 